九州大学学術情報リポジトリ

Kyushu University Institutional Repository

\title{
Accumulation of Nitrogen Supplied as Ammonium in the Root Tips of Aluminum-Stressed Wheat Cultivars Differing in Aluminum Sensitivity
}

Ikeda, Motoki

Laboratory of Plant Nutrition, Department of Agricultural Chemistry, Faculty of Agriculture, Kyushu University

Yamanishi, Tomoharu

Laboratory of Plant Nutrition, Department of Agricultural Chemistry, Faculty of Agriculture, Kyushu University

https://doi.org/10.5109/24303

出版情報：九州大学大学院農学研究院紀要. 44 (1/2)，pp.33-38，1999-11. Kyushu University バージョン：

権利関係 : 


\title{
Accumulation of Nitrogen Supplied as Ammonium in the Root Tips of Aluminum-Stressed Wheat Cultivars Differing in Aluminum Sensitivity
}

\author{
Motoki Ikeda and Tomoharu Yamanishi
}

Laboratory of Plant Nutrition, Department of Agricultural Chemistry, Faculty of Agriculture, Kyushu University, Fukuoka 812-8581, Japan

(Receixed July 9, 1999 and accepted August 24, 1999)

\begin{abstract}
Ammonium labeled with ${ }^{15} \mathrm{~N}$ was supplied for two days to two wheat (Triticum aestivum L.) cultivars treated with Al. At a low Al concentration, root clongation was greatly inhibited by treatment for 24 hours in cultivar Chikushikomugi, while in cultivar Shirosanjyaku, significant. inhibition of root clongation required treatment for 48 hours. Decreases in $p H$ values of nutrient solution werc greater in Shirosanjyaku than Chikushikomugi and smaller at a higher Al concentration in both the varieties. These results indicale that uptake of ammonium was more strongly inhibited by Al in Chikushikomugi than Shirosanjyaku. Accumulation of newly absorbed nitrogen $\left({ }^{15} \mathrm{~N}\right)$ was decreased at a low $\mathrm{Al}$ concentration in the apical part of root tip $(0-12 \mathrm{~mm})$ of Chikushikomugi. In Shirosanjyaku treated with a low concentration of $\mathrm{Al}$, accumulation of ${ }^{5} \mathrm{~N}$ increased rather than inhibited. Al a high $\mathrm{Al}$ concentration, accumulation of N slightly decreased in the root tip of Shirosanjyaku. Accumulation of ${ }^{15} \mathrm{~N}$ in four segments dissected from a root tip was differently affected between Shirosanjyaku and Chikushikomugi. It is considered that Shirosanjyaku is able to maintain active nitrogen metabolism in the root tip under $\mathrm{Al}$-stress conditions compared to Chikushikomugi.
\end{abstract}

\section{INTRODUCTION}

The most adverse factor related to growth inhibition of plants in acid soils is aluminum (Al) toxicity (Marschner, 1995). The distinct and rapid effect of $\mathrm{Al}$ appears as the inhibition of root elongation (Barcelo et al., 1996). Differential Al tolerance of wheat cultivars has been widely demonstrated (Polle et al., 1978). Tolerant wheat cultivars are able to excrete malate to chelate toxic $\mathrm{Al}$ species in low $\mathrm{pH}$ media and thereby to protect root apices from $\mathrm{Al}$ toxicity (Delhaize et al., 1993). On the other hand, it is well known that $\mathrm{Al}$ affects uptake and transport of essential mineral elements such as $\mathrm{K}, \mathrm{Ca}, \mathrm{Mg}$ and $\mathrm{P}$ in crop plants including wheat (Taylor and Foy, 1985; Ohki, 1985; Huang and Grunes, 1992). With regard to uptake of $\mathrm{N}$, relationships between varietal differences in $\mathrm{Al}$ tolerance and $\mathrm{N}$ sources were extensively investigated in soybean (Klotz and Horst, 1988), wheat (Taylor, 1988), and sorghum (Galvez and Clark, 1991) because nitrate and ammonium are able to differentialy change solution $\mathrm{pH}$ after uptake of them and thereby to change the concentrations of toxic $\mathrm{Al}$ species in culture solution. However, the preference of individual varieties to ammonium or nitrate did not always connect sensitivity to $\mathrm{Al}$ of those plants. When $\mathrm{Al}$ was added to culture solution, uptake of nitrate was inhibited in sorghum (Keltjens, 1988), maize (Durieux et al., 1993) and wheat (de Andrade et al., 1996), but it was enhanced in an Al-sensitive barley cultivar (Nichol et al., 1993). In soybean, short-term exposure to $\mathrm{Al}$ inhibited the uptake of ${ }^{15} \mathrm{NO}_{3}^{-}$to a similar extent between two cultivars with different Al-tolerance (Lazof et al., 1994). 
When plants were supplied with ammonium in nutrient media, uptake of ammonium was inhibited by Al in barley (Nichol et al., 1993) and rice (Hai et al., 1989) but it was not affected in sorghum (Keltjens, 1988), wheat (de Andrade et al., 1996) and maize (Calba and Jaillard, 1997). Inhibition of absorption of inorganic nitrogen by Al might lead to less accumulaton of nitrogen in roots and shoots. Although nitrogen is required at sufficient amounts for maintenance of vital metabolic activity in roots, little work dealt with nitrogen accumulation under $\mathrm{Al}-$ stress conditions in root tips, which are the primary site of action for Al toxicity. In the present study we investigated accumulation of nitrogen supplied as ammonium in simple nutrient solution in the root tip sections of two wheat varieties that have different sensitivity to $\mathrm{Al}$ and had been imposed by $\mathrm{Al}$ stress.

\section{MATERIALS AND METHODS}

Seeds of two cultivars of wheat (Triticum aestivum L.), Al-sensitive cultivar Chikushikomugi (CK) and Al-tolerant one Shirosanjyaku (SS), were sterilized in $\mathrm{NaClO}$ solution ( $1 \%$ active chlorine) for $60 \mathrm{~min}$, washed with deionized water, and placed in a petri dish at $20^{\circ} \mathrm{C}$ in the dark for two days. Sixteen germinating seedlings were transplanted onto the plastic mesh sheet of a floating raft, and were cultured in a $5.5 \mathrm{~L}$ vat containing aerated $0.2 \mathrm{mM} \mathrm{CaCl}_{2}$ (pH 4.5) solution in a growth chamber $\left(20^{\circ} \mathrm{C}, 70 \%\right.$ relative humidity, $250 \mu \mathrm{mol} \mathrm{m}{ }^{2} \mathrm{~s}$ ' photon flux density) of the Biotron Institutc, Kyushu University. For treating wheat plants with $\mathrm{Al}$, parts of the rafts were transferred into $0.2 \mathrm{mM} \mathrm{CaCl}_{2}$ solution (pH 4.5) containing $10 \mu \mathrm{M}$ and $100 \mu \mathrm{M} \mathrm{AlCl}_{1,}$, and plants on the rafts were grown for one day, two days and three days prior to the supply of $\mathrm{N}$-ammonium. Control plants were cultured in $0.2 \mathrm{mM} \mathrm{CaCl}_{2}$ solution ( $\mathrm{pH} \mathrm{4.5)} \mathrm{for} \mathrm{six} \mathrm{days.}$

Eight days after germination, all plants on rafts were washed with deionized water and then with $0.2 \mathrm{mM} \mathrm{CaCl}_{2}$ solution three times. Those plants were grown in $500 \mathrm{~mL}$ of aerated solution of $0.2 \mathrm{mM} \mathrm{CaCl}$, solution ( $\mathrm{pH} 4.5$ ) containing $1 \mathrm{mM}\left({ }^{15} \mathrm{NH}_{4}\right)_{2} \mathrm{SO}_{4}(30.5$ atom $\%{ }^{11} \mathrm{~N}$ ) for two days. Harvested roots were washed with running water and then deionized water to well remove ammonium from the root surface. Then, the length of the longest primary root of each plant was measured with a rule, and the $\mathrm{pH}$ of each nutrient solution was measured by the glass electrode method. Plants were frozen, lyophilized and stored in a desiccater. The longest primary root of each plant was dissected with a razor at $2,6,9$ and $12 \mathrm{~mm}$ from the apex of the root.

Nitrogen content of the root segment was quantified by the method of Heberer et al. (1985). Briefly, the segment was digested in $\mathrm{H}_{2} \mathrm{SO}_{4}$ with sequential additions of $30 \% \mathrm{H}_{2} \mathrm{O}_{2}$. An aliquot of the digest was used for colorimetric determination of $\mathrm{NH}_{4}-\mathrm{N}$ by the indophenol method. For ${ }^{15} \mathrm{~N}$ analysis, nitrogen contained in the root segment was gassified to $\mathrm{N}_{2}$ with both $\mathrm{CaO}$ granules and $\mathrm{CuO}$ wires in a vacuum discharge glass tube by Dumas' method (Kumazawa and Goleb, 1969). Abundance of ${ }^{15} \mathrm{~N}$ was measured by emission spectrometry with a NIA-1 analyzer (Jasco Co., Hachioji, Japan).

\section{RESULTS}

Aluminum treatment caused the inhibition of root elongation in two wheat varieties (Table 1). The higher concentration of $\mathrm{Al}$ and the longer treatment period was, the 
Table 1. Effects of $\mathrm{Al}$ concentration and treatment period on root elongation of wheat cultivars differing in Al tolerance and medium- $\mathrm{pH}$ decreases due to ammonium uptake.

\begin{tabular}{lcccc}
\hline Cultivar & $\begin{array}{c}\text { Al } \\
\text { concentration } \\
(\mu \mathrm{M})\end{array}$ & $\begin{array}{c}\text { Treatment } \\
\text { period } \\
(\mathrm{h})\end{array}$ & $\begin{array}{c}\text { Root } \\
\text { length } \\
(\mathrm{mm})\end{array}$ & $\begin{array}{c}\mathrm{pH} \\
\text { decrease }\end{array}$ \\
\hline Chikushi- & 0 & 0 & $104 \mathrm{a}$ & 0.98 \\
komugi & 10 & 24 & $85 \mathrm{~b}$ & 0.87 \\
& 10 & 48 & $82 \mathrm{~b}$ & 0.83 \\
& 10 & 72 & $77 \mathrm{c}$ & 0.67 \\
& 100 & 24 & $85 \mathrm{~b}$ & 0.52 \\
& 100 & 48 & $77 \mathrm{c}$ & 0.46 \\
Shiro- & 100 & 72 & $58 \mathrm{~d}$ & 0.53 \\
sanjyaku & 0 & 0 & $83 \mathrm{a}$ & 1.01 \\
& 10 & 24 & $75 \mathrm{ab}$ & 0.89 \\
& 10 & 48 & $68 \mathrm{bc}$ & 0.82 \\
& 10 & 72 & $63 \mathrm{~cd}$ & 0.76 \\
& 100 & 24 & $71 \mathrm{bc}$ & 0.71 \\
& 100 & 48 & $67 \mathrm{bc}$ & 0.71 \\
& 100 & 72 & $56 \mathrm{~d}$ & 0.59 \\
\hline
\end{tabular}

Means followed by the same letter in each cultivar are not significantly different at the $5 \%$ level according to Duncan's multiple range test.

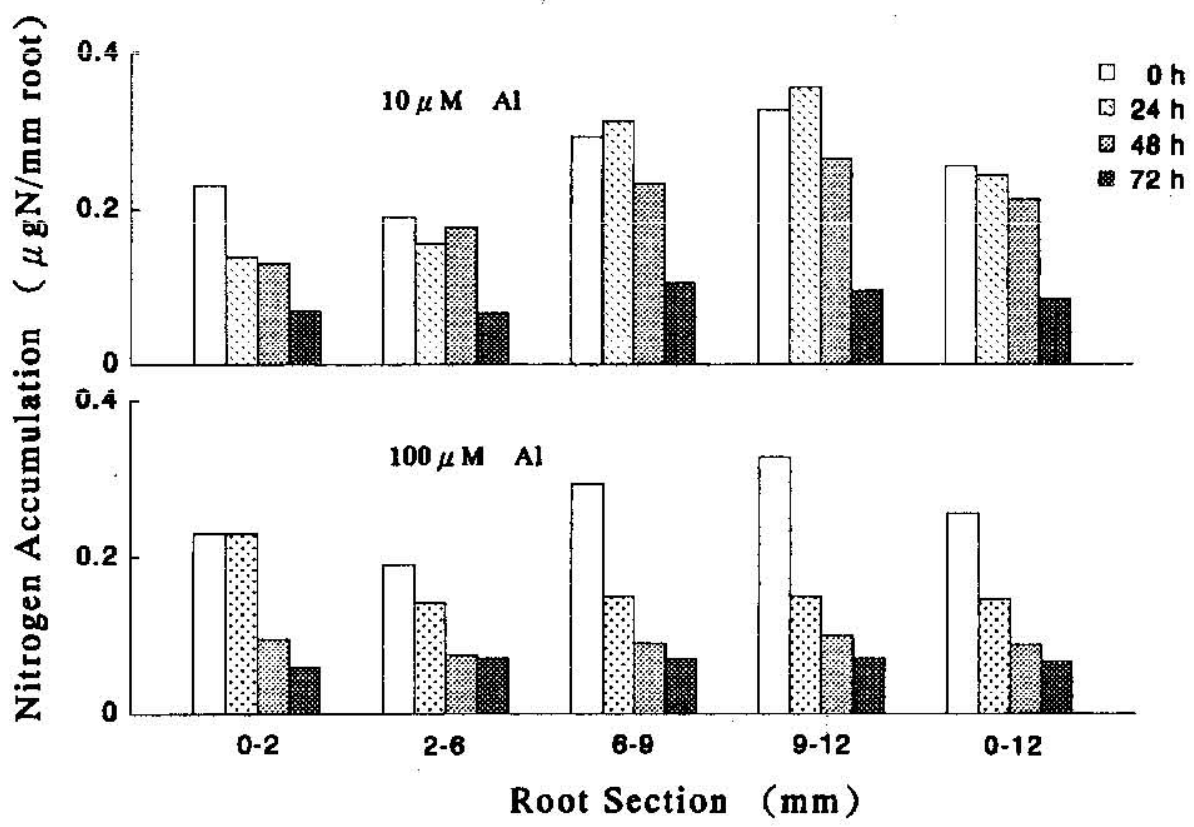

Fig. 1. Effect of $\mathrm{Al}$ concentration and treatment period on the accumulation of nitrogen supplied as ammonium in the root tip of Al-sensitive wheat cultivar, Chikushikomugi. 


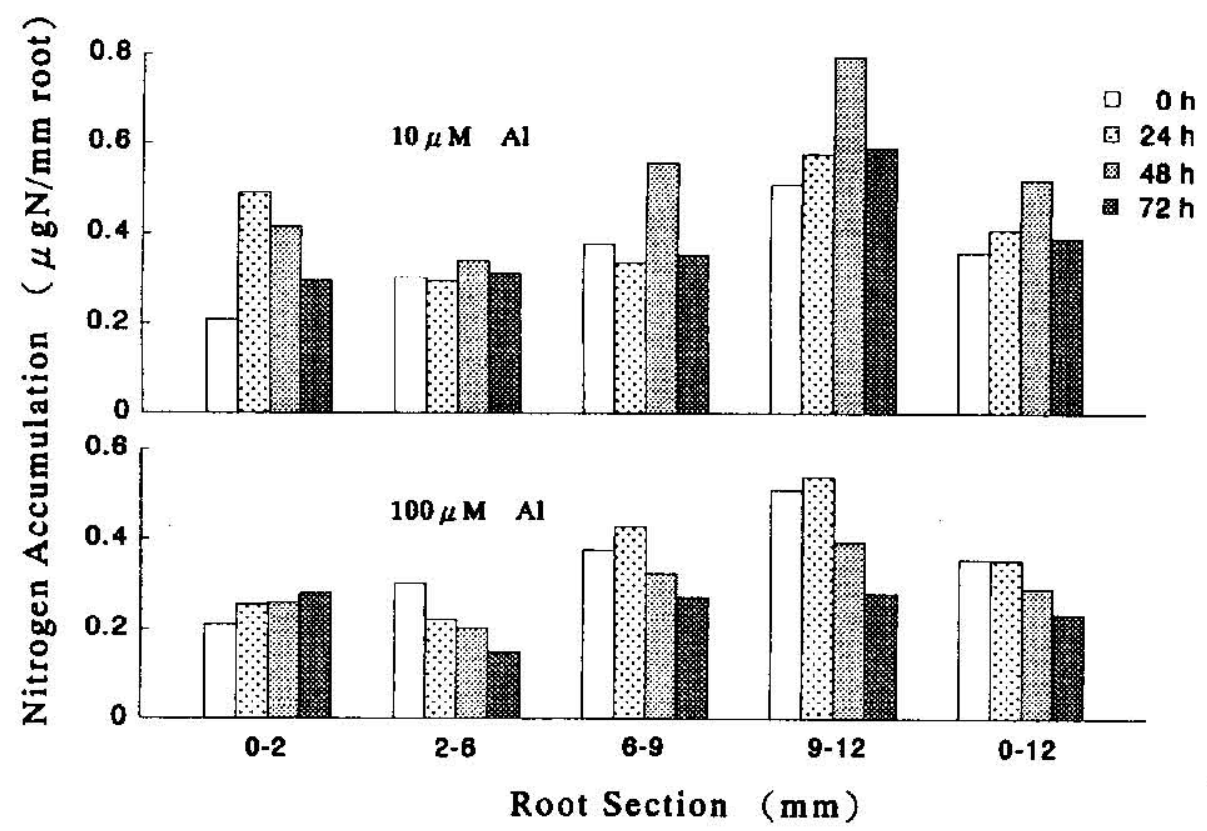

Fig. 2. Effect of $\Lambda \mathrm{l}$ conccntration and treatment period on the accurnulation of nitrogen supplied as ammonium in the root tip of Al-tolerant wheat cultivar, Shirosarijyaku.

shorter root length was. Root elongation was inhibited more greatly by $\mathrm{Al}$ treatment in $\mathrm{CK}$ plants than SS plants. Decreases in $\mathrm{pH}$ values of nutrient solution due to ammonium uptake became smaller by treatment with higher concentrations of $\mathrm{Al}$ and for longer periods (Table 1). In Al-stressed plants, $\mathrm{pH}$ values more greatly decreased in SS plants than CK plants.

Accumulation of nitrogen $\left({ }^{15} \mathrm{~N}\right)$ absorbed as ammonium in each section of the tips of primary roots was shown in Figs. 1 and 2. Accumulation of ${ }^{15} \mathrm{~N}$ per unit root length was basipetally larger in the root tips of control plants of both the cultivars, partly depending on the diameter of each section. Slightly larger amounts of ${ }^{15} \mathrm{~N}$ were present in each section of SS plants than that of CK plants.

In $\mathrm{CK}$ plants treated with $10 \mu \mathrm{M} \mathrm{Al}$, accumulation of ${ }^{15} \mathrm{~N}$ in the apical section $(0-2 \mathrm{~mm})$ was suppressed even by treatment of $24 \mathrm{~h}$ and greatly suppressed by treatment of $72 \mathrm{~h}$ while that in basal sections was only slightly affected by treatment of $24 \mathrm{~h}$ and $48 \mathrm{~h}$ but greatly decreased in all the sections of roots treated for $72 \mathrm{~h}$. When CK plants had been treated with $100 \mu \mathrm{M} \mathrm{Al}$ for longer treatment periods the severe suppression of accumulation of ${ }^{15} \mathrm{~N}$ arose in all the sections.

When SS plants had been treated with $10 \mu \mathrm{M} \mathrm{Al}$, accumulation of ${ }^{15} \mathrm{~N}$ was not suppressed but increased or almost equal in all the sections. In SS plants treated with $100 \mu \mathrm{M} \mathrm{Al}$, accumulation of ${ }^{15} \mathrm{~N}$ always increased in the apical section and decreased in 
other sections of roots treated for $48 \mathrm{~h}$ and $72 \mathrm{~h}$.

When plants were treated with $100 \mu \mathrm{M} \mathrm{Al}$ for $72 \mathrm{~h}$, accumulation of ${ }^{15} \mathrm{~N}$ decreased only by $34 \%$ in the whole root section $(0-12 \mathrm{~mm})$ of SS plants while it did by $74 \%$ in that of CK plants (Figs. 1 and 2).

\section{DISCUSSION}

It is confirmed from results on the inhibition of root elongation that cultivar SS is more tolerant to $\mathrm{Al}$ than cultivar CK (de Andrade et al., 1996). The $\mathrm{pH}$ changes directly reflect uptake of ammonium by plants from ammonium media (Breteler, 1973). Therefore it is considered that uptake of ammonium by whole plants might be reduced by the treatment with $\mathrm{Al}$ and the extent of its inhibition might be greater in CK plants than SS plants. At the same time, the total accumulation of newly absorbed nitrogen in a root tip was more greatly inhibited in CK plants than SS plants. In contrast, de Andrade et al. (1996) reported that the cumulative uptake of ammonium for 12 days was little affected even in the presence of $120 \mu \mathrm{M} \mathrm{Al}$ in the same varieties as examined in the present study. This might result from that de Andrade et al. (1996) used 15-day-old wheat plants, which might be less injured by $\mathrm{Al}$ and/or absorb all of added ammonium from the nutrient solution during each culture period since ammonium absoption was not completely inhibited by Al.

Because in the present experiment wheat plants were treated with $\mathrm{Al}$ and thereafter supplied with ${ }^{15} \mathrm{~N}$-labeled ammonium in nutrient media without $\mathrm{Al}$, an interaction between $\mathrm{NH}_{4}{ }^{+}$and $\mathrm{Al}$ in nutrient media can be ruled out in the present experiment. As shown by limited root elongation due to $\mathrm{Al}$ stress, less root mass may be responsible for reduced absorption of ammonium from nutrient media. However, it cannot be excluded that functions for absorption of ammonium also might be hampered by prior exposure of roots to $\mathrm{Al}$. In rice plants a sensitive variety took up less ammonium and acidified less the culture solution containing Ȧl than a resistant one did (Hai et al., 1989).

Aluminum stress differentialy affected accumulation of newly absorbed nitrogen in each position of wheat root tips, indicating that nitrogen metabolism in those tissues might be differently disturbed in different positions of a root by the prior Al treatment. The root tip of CK plants was inore fragile in iutrogen metabolism than that of SS plants. Reduced accumulation of ${ }^{15} \mathrm{~N}$ in the root tip of $\mathrm{CK}$ plants might be basically due to strong suppression of ammonium uptake compared to SS plants (Table 1), and partly to inhibition of cell activity caused by $\mathrm{Nl}$ stress (Marschner, 1995). On the other hand, in SS plants weak Al stress could rather enhance accumulation of newly absorbed nitrogen in the root tip even though ammonium uptake by whole plants was suppressed to a lower extent. At the present time we have no evidence for explanation of this result, but it can be pointed that morphological changes, i.e. swelling of the root tip or inhibited translocation of nitrogen will be responsible for such unexpected accumulation of newly absorbed nitrogen in the root tip of SS plants.

\section{REFERENCES}

de Andrade L. R. M., M. Ikeda and J. Ishizuka 1996 Effect of nitrogen sources on aluminum toxicity in 
wheat varieties differing in tolerance to aluminum. Soil Sci. Plant Nutr., 42: 651-657

Barcelo, J., Ch. Poschenrieder, M. D. Vazquez and B. Gunse 1996 Aluminium toxicity. A challenge for plant scientists. Fert. Res., 43: 217-223

Breteler, H. 1973 A comparisun between armunium and nitrate nutrition of young sugar-beet plants grown in nutrient solutions at constant acidity. 2. Effect of light and carbohydrate supply. Neth $J$. Agr. Sci., 21: 297-307

Calba, H. and B. Jaillard 1997 Effect of aluminium on ion uptake and $\mathrm{H}^{\prime}$ release by maize. Neu Phytol., 137: $607-616$

Delhaize, E., P. R. Ryan and P. J. Randall 1993 Aluminum tolerance in wheat (Triticum aestivum L.). II Aluminum-stimulated excretion of malic acid from root apices. Plant Physiol, 103: 695-702

Durieux, R. P., W. A. Jackson, E. J. Kamprath, and R. H. Moll 1993 Inhibition of nitrate uptake by aluminium in maize. Plant Soil, 151: 97-104

Galvez, L. and R. B. Clark 1991 Nitrate and ammonium uptake and solution pH changes for Al-tolerant and $\mathrm{Al}$-sensitive sorghum (Sorghum bicolor) genotypes grown with and without aluminum. Plant Soil, 134: 179-188

Hai, T. V., T.T. Nga, and H. Laudelout 1989 Effect of aluminum on mineral nutrition of rice. Plant Soil, 114: $173-185$

Heberer, J. A., F. E. Below, and R. H. Hageman 1985 Drying method effect on leal chemical constituents of four crop species. Crop Sci., 25: 1117-1119

Huang, J. W. and D. L. Grunes 1992 Potassium/magnesium ratio effects on aluminum tolerance and mineral composition of wheat forage. Agr. J., 84: $643-650$

Keltjens, W. G. 1988 Short-term effects of $\mathrm{Al}$ on nutrient uptake, $\mathrm{H}^{\prime}$ efflux, root respiration and nitrate reductase activity of two sorghum genotypes differing in Al-susceptibility. Commun. Soil Sci. Plant Anal, 19: 1155-1163

Klotz, F. and W. J. Horst 1988 Effect of ammonium- and nitrate-nitrogen on aluminium tolerance of soybean (Glycine $\max$ L.). Plant Soil, 111: $59-65$

Kumazawa, K. and J. A. Goleb 1969 Optical emission spectrographic studies on the distribution and accumulation of nanogram amounts of ${ }^{15} \mathrm{~N}$ in rice seedlings. Plant Cell Physiol., 10: 725-731

Lazof, D. B., M. Rincon, T. W. Rufty, C. T. Mackown and T. E. Carter 1994 Aluminum accumulation and associated effects on ${ }^{15} \mathrm{NO}_{5}^{-}$influx in roots of two soybean genotypes differing in Al tolerance. Plant Soil, 164: 291-297

Marschuner, H. 1995 Mineral Nutrition of Higher Plants. Academic: Press, London

Nichol, B. E., L. A. Oliveria, A. D. M. Glass and M. Y. Siddiqi 1993 The effects of aluminum on the influx of calcium, potassium, ammonium, nitrate, and phosphate in an aluminum-sensitive cultivar of barley (Hordeum vulgare L.). Plant Physiol., 101: 1263-1266

Ohki, K. 1985 Aluminum toxicity effects on growth and mineral composition in wheat. Agr. J., 77: 951-956

Polle, E., C. F. Kozak, and J. A. Kittrick 1978 Visual detection of aluminum tolerance levels in wheat by hematoxylin staining of seedling roots. Crop Sci., 18: 823-827

Taylor, G. J. 1988 Mechanisms of aluminum tolerance in Triticum aestivum (wheat) V. Nitrogen nutrition, plant-induced $\mathrm{pH}$, and tolerance 1.0 alurirum; correlation without causuality? Can. J. Bot, 66: $694-699$

Taylor, (G. J. and C. D. Foy 1985 Effects of aluminum on the growth and element composition of 20 winter cultivars of Triticum aestivum L. (wheat) grown in solution culture. J. Plant Nutr., 8: 811-824 